\title{
Hypertonic saline-hydroxyethyl starch solution attenuates fluid accumulation in cardiac surgery patients: a randomized controlled double-blind trial
}

\author{
Kati Järvelä ${ }^{1}$, Markku Rantanen ${ }^{1}$, Tiit Kööbi ${ }^{2}$, Heini Huhtala ${ }^{3}$, Tero Sisto ${ }^{1}$ \\ ${ }^{1}$ Heart Centre Co., Tampere University Hospital, Tampere, Finland \\ ${ }^{2}$ Department of Clinical Physiology, Tampere University Hospital, Tampere, Finland \\ ${ }^{3}$ Faculty of Social Sciences, Tampere University, Tampere, Finland
}

\begin{abstract}
Background: Significant fluid retention is common after cardiac surgery with the use of cardiopulmonary bypass (CPB). The aim of the study was to evaluate the effects of hypertonic saline-hydroxyethyl starch (HS-HES) solution on fluid accumulation in patients undergoing coronary artery bypass grafting surgery (CABG).

Methods: Fifty adult male patients undergoing coronary bypass surgery were enrolled in this interventional, randomized, double-blinded study to compare HS-HES with saline solution. The study fluid $(250 \mathrm{~mL})$ was given into the venous reservoir of the CPB circuit at the time of aortic declamping.

Results: Body mass change from the baseline to the first postoperative morning was significantly less in the HS-HES group compared with the control group $(3.3 \pm 1.5 \mathrm{~kg}$ vs. $4.4 \pm 1.5 \mathrm{~kg}, P=0.022)$. In the extracellular water (ECW) or ECW-balance, there were no significant differences between the groups. The need for fluids and diuretic medication did not differ between the groups during the perioperative period.

Conclusions: Our study shows that $250 \mathrm{~mL}$ of HS-HES solution can reduce perioperative fluid accumulation to some degree in patients undergoing CABG surgery with $\mathrm{CPB}$.
\end{abstract}

Anaesthesiology Intensive Therapy 2018, vol. 50, no 2, 122-127

Key words: saline solution, hypertonic; coronary artery bypass; cardiopulmonary bypass; water

Fluid retention on the first postoperative morning after cardiac surgery is more a rule than an exception. The main reason for this is extravasation of intravascular fluid through the vascular endothelium, especially during extracorporeal circulation. A healthy vascular endothelium is coated by the endothelial glycocalyx. The glycocalyx binds plasma proteins forming an endothelial surface layer of 500 to $1000 \mathrm{~nm}$ in the microvasculature. This layer maintains the physiologic permeability barrier and prevents leukocyte and platelet adhesion which, in turn, inhibits inflammation and tissue oedema [1]. Bruegger et al. [2] have shown evidence for an acute destruction of the endothelial glycocalyx in patients undergoing aortic surgery. Cardiopulmonary bypass (CPB) decreases plasma colloid osmotic pressure increasing extravasation of the fluids during cardiac surgery and CPB.
In order to ensure adequate tissue perfusion, sufficient intravascular volume needs to be maintained despite extravasation. Profuse fluid administration is often necessary to achieve this. Weaning from CPB after declamping of the aorta is a time point where fluid administration is usually required. This has also harmful effects: highly positive fluid balance has been associated with a longer length of hospital stay in cardiac surgery patients [3].

Hypertonic saline (HS) infusion creates an osmotic gradient across the cellular membrane. Because osmolality is the driving force of water distribution, the fluid is shifted from the intracellular space into the extracellular space after HS infusion [4]. Similarly, increased intravascular osmolality after HS infusion draws fluid into the intravascular space. HS causes direct renal vasodilatation and increases 
the glomerular filtration rate, also increasing fluid excretion through the kidneys [5]. The benefit of high intravascular osmolality is short-lasting as a result of the redistribution of fluid between the intravascular, intracellular and interstitial spaces. The effect can be lengthened by adding a colloid component into the solution [6].

In this study, we aimed to test the hypothesis that $7.2 \%$ $\mathrm{NaCl}$ in hydroxyethyl starch (HES 200/0.5) given after aortic declamping can reduce fluid retention. Primary endpoints were the changes in body weight and whole-body impedance-derived extracellular water from the baseline to the first postoperative morning. Secondary endpoints were the need for fluids and diuretic medication during the perioperative period.

\section{METHODS}

Ethical approval for this study was provided by the local ethical review board (the Ethical Committee of Pirkanmaa Hospital District, Tampere, Finland). This study was conducted according to the Declaration of Helsinki. Randomization with a computer-generated randomization table was performed by a study nurse not involved in the study. Blocks of four were used to minimize the effect of any possible changes in routine patient care during the study period. The study nurse also opened the sealed opaque envelopes and prepared the study fluid with an opaque cover ensuring that the investigators, as well as all medical and nursing staff involved in patient care were blinded to the group assignment.

Patients undergoing coronary elective artery bypass grafting surgery with the use of cardiopulmonary bypass were enrolled in this study. Exclusion criteria were chronic hyponatraemia, significant renal dysfunction (glomerular

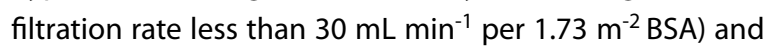
pulmonary artery catheter use (pulmonary hypertension or left ventricular ejection fraction $<40 \%$ ).

An investigator explained the study protocol to the patients. After obtaining written informed consent from the patients, they were randomized to receive either $250 \mathrm{~mL}$ of $7.2 \% \mathrm{NaCl}$ in hydroxyethyl starch (HES 200/0.5) (Hyperhaes', Fresenius Kabi) (HS-HES group) or $250 \mathrm{~mL}$ of $\mathrm{NaCl} 0.9 \%$ (Natriumklorid Braun $9 \mathrm{mg} \mathrm{mL}^{-1}$ ) (control group). The study fluid was given into the venous reservoir of the cardiopulmonary bypass circuit for a period of 30 minutes, beginning 10 minutes before the anticipated time of aortic de-clamping.

A whole-body impedance cardiography device, namely a CircMon B202 (JR Medical Ltd, Tallinn, Estonia), was used for the measurement of extracellular water (ECW), heart rate $(\mathrm{HR})$, cardiac index $(\mathrm{Cl})$, left cardiac work index (LCWI), systemic vascular resistance index (SVRI), and stroke index (SI) [7]. Measurements were performed before the induction of anaesthesia, one hour after the end of surgery (intubated) and before mobilization on the first postoperative morning (i.e. 17-20 hours after the end of the operation).

Blood samples for analysis of plasma $\mathrm{Na}$ and $\mathrm{N}$-terminal pro-BNP (NT-pro-BNP) were drawn preoperatively and on the first postoperative morning. The measurement of NT-proBNP was performed using an electrochemiluminescence immunoassay (ECLIA) with an Elecsys 2010 immunoassay analyser (Roche Diagnostics $\mathrm{GmbH}$, Basel, Switzerland). Blood samples for the analysis of haematocrit and $\mathrm{pH}$ were drawn preoperatively, one hour after the end of surgery and on the first postoperative morning. Haematocrit and $\mathrm{pH}$ were analysed with Gem premier 3,000 (Instrumentarium Laboratory, Helsinki, Finland). All patients were weighed with a calibrated scale in the sitting position on the ward before the operation and on the first postoperative morning. The weight of the chest tubes and monitoring equipment was supported by a nurse during weighing.

General anaesthesia was induced and maintained with sufentanil and propofol. Cisatracurium was used to facilitate tracheal intubation and for muscle relaxation. There was no predefined dosing protocol for anaesthetic medication. A roller pump with a non-pulsatile flow at 2.0-3.0 $\mathrm{L} \mathrm{min}^{-1}$ $\mathrm{m}^{-2}$ and a membrane oxygenator were used. The CPB circuit was primed with Ringer's acetate. Cold blood antegrade and retrograde cardioplegias were administered intermittently to protect the myocardium. Noradrenaline was used to keep mean arterial pressure at $50-80 \mathrm{~mm} \mathrm{Hg}$ during the $C P B$. Haematocrit was maintained above 0.20 during the $C P B$ and above 0.25 after weaning from the CPB. The patients were near to being normothermic throughout the whole procedure.

The goal for haemodynamic support was to maintain central venous saturation $\left(\mathrm{ScvO}_{2}\right)$ above $55 \%$. CVP was maintained at the level of $10-15 \mathrm{~mm} \mathrm{Hg}$ by infusing saline and Ringer's solution. Mean arterial pressure after weaning from CPB was maintained at between $60-90 \mathrm{~mm} \mathrm{Hg}$ with the aid of noradrenaline or sodium nitroprusside when needed. Dobutamine was administered if $\mathrm{ScvO}_{2}$ was less than $55 \%$ or lactataemia occurred after volume loading. After the optimization of haemodynamics, furosemide was administered if diuresis was less than $1 \mathrm{~mL} \mathrm{~kg}^{-1} \mathrm{~h}^{-1}$.

The sample size used in the study was based on our previous studies [8]. Using a 2-sided alpha of $0.05 ;$ a $1.5 \mathrm{~kg}$ difference in weight gain on the first postoperative morning can be detected with a power of $80 \%$ with 17 patients in both study groups. In case of drop outs, we decided to take 25 patients in each group. Binominal data were analysed with the Fisher's test. Pairwise comparisons were done with the t-test or the Mann-Whitney U-test if needed. A $P$-value $<0.05$ was considered significant. The data were analysed using IBM SPSS Statistics 20.0. 


\section{RESULTS}

The predetermined number of 50 adult male patients was randomized in the study. Two patients were excluded from the study as the operation plan was changed in the operation room (valve surgery and off-pump surgery). Another six patients were excluded from the analysis because of postoperative bleeding requiring reoperation. In the final analysis, there were 21 patients in both study groups. Demographic data, operative data and fluid input and output are shown in Table 1. Eight patients in the control group and seven patients in the HS-HES group received red blood cells (NS). Seven patients in the control group and four patients in the HS-HES group received furosemide (NS). The body weight change from the baseline to the first postoperative morning was significantly less in the HS-HES group compared to the control group $(3.3 \pm 1.5 \mathrm{~kg}$ vs. $4.4 \pm 1.5 \mathrm{~kg}$, $P=0.022$ ) (Fig. 1). There were no differences between the groups in the haematocrit, NT-pro-BNP or pH values (Table 2). The maximum plasma sodium ( $\mathrm{p}-\mathrm{Na}$ ) was higher in the HSHES group ( $145.9 \pm 1.9$ vs. $141.1 \pm 2.9, P=0.000)$. P-Na was still higher in the HS-HES group on the first postoperative morning although the mean values were within normal limits in both groups $(141.9 \pm 2.8$ vs. $139.1 \pm 3.4, P=0.007)$. There were no significant differences between the groups in the ECW or ECW-balance values as well as in haemodynamic

Table 1. Demographic and perioperative data (mean \pm SD)

\begin{tabular}{lccc}
\hline & $\begin{array}{c}\text { HS-HES group } \\
\mathrm{N}=\mathbf{2 1}\end{array}$ & $\begin{array}{c}\text { Control group } \\
\mathrm{N}=\mathbf{2 1}\end{array}$ & $P$-value \\
\hline Age (years) & $66.9 \pm 7.2$ & $65.2 \pm 10.6$ & 0.556 \\
Body mass $(\mathrm{kg})$ & $88.1 \pm 14.1$ & $84.7 \pm 15.1$ & 0.468 \\
BSA $\left(\mathrm{m}^{2}\right)$ & $2.0 \pm 0.2$ & $2.0 \pm 0.2$ & 0.351 \\
X-clamp $(\mathrm{min})$ & $86 \pm 32$ & $73 \pm 28$ & 0.175 \\
Fluids 24h $(\mathrm{mL})$ & $11826 \pm 1655$ & $11658 \pm 2045$ & 0.774 \\
Diuresis $24 \mathrm{~h}(\mathrm{~mL})$ & $3731 \pm 903$ & $3251 \pm 869$ & 0.090 \\
Drainage $(\mathrm{mL})$ & $865 \pm 299$ & $1010 \pm 291$ & 0.125 \\
\hline
\end{tabular}

BSA: body surface area; $X$ clamp: aortic cross-clamp time data (Table 3). Pulse wave velocity was slightly higher in the HS-HES group one hour after the end of surgery $(P=0.050)$. There were no adverse events reported as drug-related in either study group.

\section{DISCUSSION}

Our results show that fluid accumulation during cardiac surgery can be reduced using hypertonic saline-hydroxyethyl starch solution: weight gain in HS-HES group was statistically significantly less compared with the control group. The patient's weight takes into account all factors affecting overall fluid balance: fluid input, diuresis, evaporation and blood loss. Kvalheim et al. [9] have also shown that the infusion of hypertonic saline/starch solution during a cardiopulmonary bypass reduces fluid overload [9]. They infused hypertonic saline-hydroxyethyl starch solution $1 \mathrm{~mL}$ $\mathrm{kg}^{-1} \mathrm{~h}^{-1}$ for four hours which resulted in a lower fluid gain until the next morning compared with the control group receiving the same amount of Ringer's solution. Parrinello et al. [10] have shown HS to be beneficial also to patients with acute decompensated heart failure: the addition of $\mathrm{HS}$

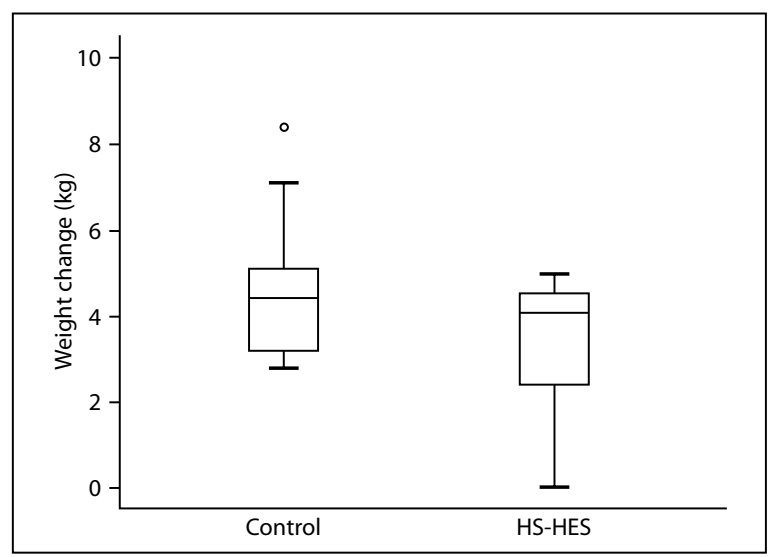

Figure 1. Weight change from baseline to the first postoperative morning (median, quartiles). The difference between the groups was statistically significant $(P=0.020)$

Table 2. Laboratory values (mean \pm SD)

\begin{tabular}{|c|c|c|c|c|}
\hline & Timepoint & $\begin{array}{l}\text { HS-HES group } \\
\quad \mathrm{N}=21\end{array}$ & $\begin{array}{l}\text { Control group } \\
\qquad N=21\end{array}$ & $P$-value \\
\hline \multirow[t]{3}{*}{$\operatorname{Hct}\left(L^{-1}\right)$} & Baseline & $0.42 \pm 0.03$ & $0.42 \pm 0.03$ & 0.620 \\
\hline & $1 \mathrm{~h}$ after surgery & $0.32 \pm 0.04$ & $0.31 \pm 0.04$ & 0.555 \\
\hline & $1^{\text {st }}$ postop day & $0.32 \pm 0.03$ & $0.31 \pm 0.03$ & 0.473 \\
\hline \multirow[t]{2}{*}{$\mathrm{BNP}\left(\mathrm{ng} \mathrm{L^{-1 }}\right)$} & Baseline & $426 \pm 661$ & $311 \pm 449$ & 0.513 \\
\hline & $1^{\text {st }}$ postop day & $1227 \pm 1227$ & $1057 \pm 771$ & 0.477 \\
\hline \multirow[t]{3}{*}{$\mathrm{pH}$} & Baseline & $7.45 \pm 0.04$ & $7.43 \pm 0.05$ & 0.272 \\
\hline & 1h after surgery & $7.39 \pm 0.03$ & $7.38 \pm 0.07$ & 0.352 \\
\hline & $1^{\text {st }}$ postop day & $7.39 \pm 0.04$ & $7.37 \pm 0.03$ & 0.100 \\
\hline
\end{tabular}

Hct: haematocrit; BNP: N-terminal pro-BNP 
Table 3. Haemodynamic data and extracellular water (mean \pm SD)

\begin{tabular}{|c|c|c|c|c|}
\hline & Timepoint & $\begin{array}{l}\text { HS-HES group } \\
\qquad N=21\end{array}$ & $\begin{array}{l}\text { Control group } \\
\qquad N=21\end{array}$ & $P$-value \\
\hline $\begin{array}{l}\mathrm{HR} \\
\left(\mathrm{min}^{-1}\right)\end{array}$ & $\begin{array}{c}\text { Baseline } \\
\text { 1h after surgery } \\
1^{\text {st }} \text { postop day }\end{array}$ & $\begin{array}{l}60.3 \pm 7.9 \\
69.1 \pm 9.7 \\
78.5 \pm 9.4\end{array}$ & $\begin{array}{c}63.2 \pm 9.2 \\
66.5 \pm 11.5 \\
79.7 \pm 7.5\end{array}$ & $\begin{array}{l}0.277 \\
0.429 \\
0.641\end{array}$ \\
\hline $\begin{array}{l}\text { MAP } \\
(\mathrm{mm} \mathrm{Hg})\end{array}$ & $\begin{array}{c}\text { Baseline } \\
\text { 1h after surgery } \\
1^{\text {st }} \text { postop day }\end{array}$ & $\begin{array}{l}94.5 \pm 7.8 \\
77.0 \pm 6.6 \\
79.8 \pm 9.5\end{array}$ & $\begin{array}{c}91.5 \pm 13.1 \\
75.7 \pm 10.3 \\
80.8 \pm 7.4\end{array}$ & $\begin{array}{l}0.374 \\
0.632 \\
0.706\end{array}$ \\
\hline $\begin{array}{l}\text { CVP } \\
(\mathrm{mm} \mathrm{Hg})\end{array}$ & $\begin{array}{c}\text { Baseline } \\
\text { 1h after surgery } \\
1^{\text {st }} \text { postop day }\end{array}$ & $\begin{array}{l}9.7 \pm 3.2 \\
9.9 \pm 2.7 \\
8.1 \pm 3.4\end{array}$ & $\begin{array}{l}9.5 \pm 2.0 \\
8.8 \pm 3.9 \\
8.0 \pm 2.9\end{array}$ & $\begin{array}{l}0.864 \\
0.220 \\
0.923\end{array}$ \\
\hline $\begin{array}{l}\mathrm{Cl} \\
\left(\mathrm{L} \mathrm{min}^{-1} \mathrm{~m}^{-2}\right)\end{array}$ & $\begin{array}{c}\text { Baseline } \\
\text { 1h after surgery } \\
1^{\text {st }} \text { postop day }\end{array}$ & $\begin{array}{l}2.57 \pm 0.51 \\
2.07 \pm 0.48 \\
2.64 \pm 0.38\end{array}$ & $\begin{array}{l}2.62 \pm 0.44 \\
2.02 \pm 0.56 \\
2.45 \pm 0.50\end{array}$ & $\begin{array}{l}0.744 \\
0.781 \\
0.172\end{array}$ \\
\hline $\begin{array}{l}\text { SI } \\
\left(\mathrm{mL} \mathrm{m}^{-2}\right)\end{array}$ & $\begin{array}{c}\text { Baseline } \\
\text { 1h after surgery } \\
1^{\text {st }} \text { postop day }\end{array}$ & $\begin{array}{l}42.6 \pm 6.7 \\
29.7 \pm 5.0 \\
33.8 \pm 3.8\end{array}$ & $\begin{array}{l}41.6 \pm 5.3 \\
30.5 \pm 7.0 \\
30.8 \pm 5.9\end{array}$ & $\begin{array}{l}0.596 \\
0.669 \\
0.058\end{array}$ \\
\hline $\begin{array}{l}\text { LCWI } \\
\left(\mathrm{kg} \mathrm{m} \mathrm{m}^{-2}\right)\end{array}$ & $\begin{array}{c}\text { Baseline } \\
\text { 1h after surgery } \\
1^{\text {st }} \text { postop day }\end{array}$ & $\begin{array}{l}3.29 \pm 0.76 \\
2.17 \pm 0.59 \\
2.86 \pm 0.53\end{array}$ & $\begin{array}{l}3.27 \pm 0.79 \\
2.06 \pm 0.56 \\
2.71 \pm 0.63\end{array}$ & $\begin{array}{l}0.921 \\
0.541 \\
0.402\end{array}$ \\
\hline $\begin{array}{l}\text { PWV } \\
\left(\mathrm{m} \mathrm{s}^{-1}\right)\end{array}$ & $\begin{array}{c}\text { Baseline } \\
\text { 1h after surgery } \\
1^{\text {st }} \text { postop day }\end{array}$ & $\begin{array}{l}10.95 \pm 2.20 \\
10.74 \pm 2.47 \\
11.14 \pm 2.24\end{array}$ & $\begin{array}{c}10.07 \pm 2.02 \\
9.38 \pm 1.85 \\
9.96 \pm 1.80\end{array}$ & $\begin{array}{l}0.184 \\
0.050 \\
0.067\end{array}$ \\
\hline $\begin{array}{l}\text { SVRI } \\
\left(\text { dyn s cm } \mathrm{cm}^{-5} \mathrm{~m}^{-2}\right.\end{array}$ & $\begin{array}{c}\text { Baseline } \\
\text { 1h after surgery } \\
1^{\text {st }} \text { postop day }\end{array}$ & $\begin{array}{l}3049 \pm 683 \\
3123 \pm 717 \\
2467 \pm 474\end{array}$ & $\begin{array}{c}2860 \pm 590 \\
3243 \pm 1076 \\
2759 \pm 731\end{array}$ & $\begin{array}{l}0.342 \\
0.673 \\
0.132\end{array}$ \\
\hline $\begin{array}{l}\text { ECW } \\
\text { (L) }\end{array}$ & $\begin{array}{c}\text { Baseline } \\
\text { 1h after surgery } \\
1^{\text {st }} \text { postop day }\end{array}$ & $\begin{array}{l}13.1 \pm 1.7 \\
15.2 \pm 2.5 \\
16.3 \pm 3.0\end{array}$ & $\begin{array}{l}13.0 \pm 2.1 \\
15.3 \pm 2.5 \\
16.7 \pm 3.2\end{array}$ & $\begin{array}{l}0.949 \\
0.911 \\
0.691\end{array}$ \\
\hline
\end{tabular}

HR: heart rate; MAP: mean arterial pressure; CVPP: central venous pressure; Cl: cardiac index; SI: stroke index; LCWI: left cardiac work index; PWV: pulse wave velocity; SVRI: systemic vascular resistance index; ECW: extracellular water

in the treatment resulted in body hydration normalization together with reduced cardiac troponin $I$.

The intravascular hypertonic benefit of HS is fairly short-lasting as a result of the redistribution of fluid between the body compartments. The effect can be extended if a colloid component is added into the solution. According to the European consensus statement, HES and gelatine are not recommended in patients with a risk of acute kidney injury, with cardiac surgery patients most likely belonging to this patient group [11]. Therefore, the use of HS-HES solution should be used only after careful evaluation by a clinician. Considering the small amount of HES (250 mL) in this HS-HES solution, a single dose may be justified by its positive effect on overall fluid balance. Van Haren et al. [12] showed a reduction in the need for on-going fluid resuscitation in patients with septic shock after HS administration [12].

Although the amount of sodium chloride infused in the HS-HES-group is fairly high and could potentially cause acidosis, in our study there was no difference between the groups in $\mathrm{pH}$-values. In fact, high sodium levels have been suggested to be beneficial for the heart after short-term global ischaemia. It was shown that in a porcine model of orthotopic heart transplantation, hypertonic saline treatment attenuates posttransplantation cardiac allograft dysfunction and improves haemodynamics [13]. Infusion of $7.5 \% \mathrm{NaCl}$ in a clinically relevant dose causes only minor changes in the acid-base balance in normovolaemic women [14]. This is in line with our study. Another animal study showed an increase in cortisol levels, suggesting that hypertonic saline infusion could be useful in critical care resuscitation, particularly in patients who are suffering from relative adrenal insufficiency [15]. Cardiac surgery certainly requires adequate stress hormone levels.

The timing of the HS-HES infusion in our study was designed to help weaning from CPB. By infusing the HS-HES solution at the time of aortic declamping, the maximum effect on plasma volume is achieved at the time of weaning from CPB. This timing may offer an extra advantage to the postischaemic heart. Harada et al. [16] reperfused postischaemic isolated dog hearts with hypernatremic perfusate and found that it ameliorated postischaemic dysfunction by preventing an increase in intracellular $\mathrm{Ca}^{2+}$, whereas in the control group an increase in intracellular $\mathrm{Ca}^{2+}$ caused 
arrhythmia and decreased $\mathrm{Ca}^{2+}$ responsiveness of the contractile elements. In our study, the pulse wave velocity was slightly higher in the HS-HES group one hour after the end of surgery. As a short term change, a higher pulse wave velocity reflects a higher tonicity of the vascular wall, which is most likely due to a higher intravascular volume. This was supported by CVP, which had a trend towards higher values in the HS-HES group although the difference was not statistically significant.

In our study, ECW did not differ between the groups despite the difference in patients' total body weight. The extra fluid accumulation in the control group was, therefore, probably mostly intracellular oedema. Our study, however, was not designed to detect the effects of intracellular oedema.

Bakker et al. [17] have shown that increased CPB time is an independent predictor of delirium after cardiac surgery. As the CPB time increases, fluid extravasation and oedema also increases in the brain. Hypertonic saline has been shown to decrease intracranial pressure (ICP) in traumatic brain injured patients without any rebound on infusion discontinuation [18]. Kvalheim et al. [19] found that in the animal group receiving hypertonic saline/dextran solution ICP remained stable during $C P B$, whereas an increase was observed in the control group. HS could, therefore, be beneficial to cardiac surgery patients with long CPB times.

There are several limitations in our study. The examined patients do not represent all cardiac surgery patients as we made an attempt to limit the great variability in heart conditions (the type of surgery and preoperative cardiac function). In this way we could also limit the variability in CPB times, which has a significant impact on fluid accumulation. The dose of HS-HES was not calculated according to patient size: we recognised that $250 \mathrm{~mL}$ is a clinically relevant for an adult patient. Obtaining haemodynamic data and fluid balance with whole-body impedance cardiography has several limitations in this setting, namely sternotomy, chest tubes, fluid in the pleural cavity etc. This may partly explain why ECW did not differ between the groups despite the difference in total body weight. Moreover, although CVP is far from being an optimal marker for volume status, in clinical settings it is an on-line measurement that can be used for awake patients, as well as for those intubated.

In conclusion, our study shows that $250 \mathrm{~mL}$ of HS-HES solution can reduce perioperative fluid accumulation in patients undergoing $C A B G$ surgery with cardiopulmonary bypass.

\section{ACKNOWLEDGMENTS}

1. We would like to thank RN Pirjo Järventausta for ECW measurements, as well as RN Auli Palmu and RN Jani Heinilä for randomisation and preparation of the study fluid.
2. Source of funding: This work was supported by a research grant from the Finnish Cultural Foundation.

3. Conflicts of interest: none.

\section{References:}

1. Reitsma S, Slaaf DW, Vink H, et al. The endothelial glycocalyx: composition, functions, and visualization. Pflugers Arch. 2007; 454(3): 345-359, doi: 10.1007/s00424-007-0212-8, indexed in Pubmed: 17256154

2. Bruegger D, Rehm M, Abicht J, et al. Shedding of the endothelial glycocalyx during cardiac surgery: on-pump versus off-pump coronary artery bypass graft surgery. J Thorac Cardiovasc Surg. 2009; 138(6): 1445-1447, doi: 10.1016/j.jtcvs.2008.07.063, indexed in Pubmed: 19660323.

3. Toraman F, Evrenkaya S, Yuce M, et al. Highly positive intraoperative fluid balance during cardiac surgery is associated with adverse outcome. Perfusion. 2004; 19(2): 85-91, doi: 10.1191/0267659104pf723oa, indexed in Pubmed: 15162922.

4. Mazzoni MC, Borgström P, Arfors KE, et al. Dynamic fluid redistribution in hyperosmotic resuscitation of hypovolemic hemorrhage. Am J Physiol. 1988; 255(3 Pt 2): H629-H637, doi: 10.1152/ ajpheart.1988.255.3.H629, indexed in Pubmed: 2458047.

5. Fujita T, Matsuda Y, Shibamoto T, et al. Effect of hypertonic saline infusion on renal vascular resistance in anesthetized dogs. Jpn J Physiol. 1991; 41(4): 653-663, indexed in Pubmed: 1791664.

6. Sirvinskas E, Sneider E, Svagzdiene M, et al. Hypertonic hydroxyethyl starch solution for hypovolaemia correction following heart surgery. Perfusion. 2007; 22(2): 121-127, doi: 10.1177/0267659107078484, indexed in Pubmed: 17708161.

7. Tahvanainen A, Leskinen M, Koskela J, et al. Whole-body impedance cardiography in the measurement of cardiac output. Crit Care Med. 1997; 25(5): 779-785, indexed in Pubmed: 9187596.

8. Järvelä K, Kaukinen S. Hypertonic saline (7.5\%) decreases perioperative weight gain following cardiac surgery. J Cardiothorac Vasc Anesth. 2002; 16(1): 43-46, indexed in Pubmed: 11854877.

9. Kvalheim VL, Farstad M, Steien E, et al. Infusion of hypertonic saline/ starch during cardiopulmonary bypass reduces fluid overload and may impact cardiac function. Acta Anaesthesiol Scand. 2010; 54(4): 485-493, doi: 10.1111/j.1399-6576.2009.02156.x, indexed in Pubmed: 19878097.

10. Parrinello G, Di Pasquale P, Torres D, et al. Troponin I release after intravenous treatment with high furosemide doses plus hypertonic saline solution in decompensated heart failure trial (Tra-HSS-Fur). Am Heart J. 2012; 164(3): 351-357, doi: 10.1016/j.ahj.2012.05.025, indexed in Pubmed: 22980301.

11. Reinhart K, Perner A, Sprung CL, et al. European Society of Intensive Care Medicine. Consensus statement of the ESICM task force on colloid volume therapy in critically ill patients. Intensive Care Med. 2012; 38(3): 368-383, doi: 10.1007/s00134-012-2472-9, indexed in Pubmed: 22323076.

12. Van Haren FMP, Sleigh J, Boerma EC, et al. Hypertonic fluid administration in patients with septic shock: a prospective randomized controlled pilot study. Shock. 2012; 37(3): 268-275, doi: 10.1097/ SHK.0b013e31823f152f, indexed in Pubmed: 22089205.

13. Badiwala MV, Ramzy D, Tumiati LC, et al. Donor pretreatment with hypertonic saline attenuates primary allograft dysfunction: a pilot study in a porcine model. Circulation. 2009; 120 (11 Suppl): S206-S214, doi: 10.1161/CIRCULATIONAHA.108.843169, indexed in Pubmed: 19752369.

14. Kolsen-Petersen JA, Nielsen JOD, Tonnesen E. Acid base and electrolyte changes after hypertonic saline (7.5\%) infusion: a randomized controlled clinical trial. Scand J Clin Lab Invest. 2005; 65(1): 13-22, indexed in Pubmed: 15859023.

15. Goy-Thollot I, Garnier F, Bonnet JM. The effects of $10 \%$ hypertonic saline, $0.9 \%$ saline and hydroxy ethyl starch infusions on hydro-electrolyte status and adrenal function in healthy conscious dogs. Res Vet Sci. 2007; 83(3): 322-330, doi: 10.1016/j.rvsc.2007.01.004, indexed in Pubmed: 17343887.

16. Harada K, Franklin A, Johnson RG, et al. Acidemia and hypernatremia enhance postischemic recovery of excitation-contraction coupling. Circ Res. 1994; 74(6): 1197-1209, indexed in Pubmed: 8187286.

17. Bakker RC, Osse RJ, Tulen JHM, et al. Preoperative and operative predictors of delirium after cardiac surgery in elderly patients. Eur J 
Cardiothorac Surg. 2012; 41(3): 544-549, doi: 10.1093/ejcts/ezr031, indexed in Pubmed: 22345177.

18. Roquilly A, Mahe PJ, Latte DD, et al. Continuous controlled-infusion of hypertonic saline solution in traumatic brain-injured patients: a 9-year retrospective study. Crit Care. 2011; 15(5): R260, doi: 10.1186/cc10522, indexed in Pubmed: 22035596.

19. Kvalheim VL, Rynning SE, Farstad M, et al. Fluid overload during cardiopulmonary bypass is effectively reduced by a continuous infusion of hypertonic saline/dextran (HSD). Scand Cardiovasc J. 2008; 42(1):63-70, doi: 10.1080/14017430701635147, indexed in Pubmed: 17896202

\section{Corresponding author:}

Kati Järvelä

Heart Centre Co. Tampere University Hospital

PO Box 2000, FIN-33521 Tampere, Finland

e-mail: kati.jarvela@sydansairaala.fi

Received: 17.08.2017

Accepted: 25.05 .2018 